\title{
Trade Policy, Infrastructural Development and Agricultural Sector Value Added in Nigeria
}

\author{
Lionel Effiom ${ }^{\mathrm{a}} \&$ Bassey Okon Ebi $^{\mathrm{b}}$
}

\begin{abstract}
The collapse of the international price of crude oil in 2015 and its attendant negative consequences on government fiscal capacity and development efforts re-echoed the need for Nigerians to return to agriculture as the surest means of conserving foreign exchange and revamping productive capacity. Within this context, this paper investigates, using the Autoregressive Distributed Lag methodology, the impact of Nigeria's trade policy and infrastructural development on agricultural value added. Findings show that in the long-run Nigeria's trade liberalisation policy is a disincentive to the growth of the agricultural sector's value added, while key components of infrastructure (roads, telecommunications and electricity consumption) had a significant relationship and positive impact on the agricultural sector. Inter alia, the paper recommends that government strengthen the current selective ban on some agricultural products while it implements the recommendations of the African Development Bank Infrastructure Plan for Nigeria.
\end{abstract}

Keywords: Trade policy; Infrastructural development; Agricultural value added; ARDL

JEL Classification: C13, C22, F13, O13, O14

\section{Introduction}

Nigeria's trade policy since 1960 has been oriented towards the development of the domestic economy through either the promotion of exports or the restriction of imports as a means to greater resource employment, productivity and output diversification. Amongst the key trade policies were Import Substitution Industrialisation (ISI), Export Promotion (EP) and the Structural Adjustment Programme (SAP) (Chete, Adeoti, Adeyinka

a Corresponding author. Department of Economics, University of Calabar, Calabar, Nigeria. Email:leoeff2002@yahoo.com

b Department of Economics, University of Calabar, Calabar, Nigeria.Email: ukotebi@unical.edu.ng 
\& Ogundele, 2014). While the first was more restrictive and pursued the objective of scaling down on Nigeria's import volume while encouraging the local production of those goods with large import elasticity, the second advocated for the production of goods for export and greater trade liberalisation for enhanced competitiveness of local products. The Structural Adjustment Programme however had deeper effects on all sectors of the economy (Ndebbio, 2006). Domestically, it altered the pattern and trend of production and consumption - citizens were compelled to look inwards to meet basic needs, instead of relying on imports. There was also massive downsizing of the public sector. On the external front, government imposed an import ban on certain basic commodities (e.g. rice, beans, sugar, dairy products, beef, live or dead birds, bird's eggs, refined vegetable oils and fats, among others) in order to encourage their domestic production. Though pursuing neoliberal policies of deregulation and trade liberalisation, it also sought to stem the tide of import-dependency and the debilitating effects of the Dutch disease syndrome on the Nigerian economy. "Dutch disease" describes a situation where the discovery of a natural resource and its subsequent exploitation leads to a decline in productivity and growth in other sectors of the economy. It is also called the natural resource curse. Thus, blighted by her status as a net-importer of food, a nation which cannot feed itself, the SAP demanded citizens must return to agriculture as a means of curtailing dependence on imported products as well as ensuring that locally produced goods used more domestic inputs in their production.

These policies, which were the theoretical pivots of Nigeria's national development plans (NDPs), show rather disappointing results when measured in relation to the performance of key sectors of the economy the agricultural sector, for instance. In concrete terms, as at 1981, Nigeria's agricultural value added as a percentage of GDP stood at 28.5\% (World Bank, 2017). It increased marginally to $32.1 \%$ in 1989 . This represented a growth rate of $4.2 \%$ at the end of the $1980 \mathrm{~s}$. In the beginning of the $1990 \mathrm{~s}$, agricultural value added as a percentage of GDP was $31.5 \%$, increasing slightly to $35.3 \%$ by 1999 (World Bank, 2017). More disappointing was the sector's performance in the 2000s. From $26.0 \%$ in 2000, it decreased to $23.8 \%$ in 2010 and by 2015, it plummeted further to $20.8 \%$ (World Bank, 2017). Indeed, apart from 1984 and 2001 when the sector recorded growth rates of $17.5 \%$ and $55.1 \%$ respectively, all other years from 1981 witnessed very disappointing growth rates of agricultural value added in single digits. 
More worrisome is the realisation that from its peak performance of $55 \%$ in 2001 , it drastically nosedived in 2002 to a paltry $6.9 \%$.

The performance of the ISI strategy in relation to the first NDP revealed that Nigeria lacked the technological knowhow to produce hitherto imported goods, now banned as a result of the policy. Secondly, the domestic factor endowments of the country were neglected in the pursuit of industrialisation. In her quest for industrialisation, the agricultural sector was still neglected with the rising contribution of the petroleum sector to the GDP, which grew from 20.01\% in 1978 to $46.3 \%$ in 1979 (World Bank, 2017). It was however the second NDP that redressed the shortcomings of the ISI within the first NDP. As Chete et al. (2014) notes, "This was the first systematic effort to create an industrial structure linked to agriculture, transport, mining and quarrying." In other words, embedded in the aforementioned trade policies was the objective of providing critical infrastructure to support productivity in the agricultural sector (Manyong et al., 2005). This further implies that previous plans did not emphasise the critical role of the agricultural sector's value chain in boosting the nation's industrial output. Key amongst these was the development of rural-urban roads as a means of easing the constraints faced by farmers in connecting to demand centres. As noted by Ojo (1991), a good indicator of efficient agriculture is its ability to provide adequate food for the population. Thus, total food production measured in grain production grew by $2.1 \%$ a year between 1981 and 1985 .

The question is: how has the integration of these critical sectors within the policy matrix, especially as between infrastructural development and agricultural sector performance paid off? In particular, to what extent has Nigeria's trade policy impacted the development of agricultural infrastructure in Nigeria? And in turn, what is the joint impact of trade policy and infrastructure development on agricultural value added in Nigeria? These are the questions that claim our attention in this paper.

It must be stressed that a plethora of studies exist on the agricultural sector in Nigeria. These include those which investigate the effect of macro policies on the sector (Ajudua \& Davis, 2015; Odior, 2014; Aroriode \& Ogunbadejo, 2014; Muftaudeen Hussainatu, 2014; Eyo, 2008) to studies which explore the effect of infrastructure on agricultural sector performance (Anowor, 2013); to those which examine the impact of federal government expenditure on agricultural output (Iganiga Unemhilin, 2011) and those which investigate the effect of government agricultural expenditure on 
economic growth (Michael, 2017; Shuaib et al., 2015). In particular, Ogunleye et al. (2018) explores the impact of road transport infrastructure on the development of Nigeria's agricultural sector. These studies and many more do not deal with the narrow and more significant elements of agricultural sector development, namely, its value added. They mostly deal with agricultural sector GDP and not the enhancement of its raw output. Secondly existing studies on the agricultural sector rarely seek to determine the impact of trade policies on agricultural sector performance, neither are there any empirical quantification of the joint impact of trade policies and agricultural infrastructure on agricultural sector value added. The present effort seeks to contribute to this identified knowledge gap. To provide answers to these enquiries, the next section reviews the literature to provide the context of the ensuring analysis, while Section 3 discusses the methodology, model and its theoretical underpinning. Sections 4 and 5 present and discuss the results respectively, while Section 6 concludes the paper.

\section{Literature Review}

\subsection{Nigeria's trade policy and agricultural sector value added}

Agricultural value added connotes the entire hub of manufacturing procedures which result in an enhancement of the value of primary agricultural produce. It is a positive change in the physical condition of a primary product. It is the increase in the economic value of a good via specific production processes which induces the consumer to be willing to pay a price over analogous but undifferentiated goods. Historically, the agricultural sector in Nigeria has been influenced by several policies, among which is trade policy. In reviewing Nigeria's trade policy, three policy phases must be brought within the orbit of discourse. These include the prestructural adjustment phase which spanned 1970 to 1985, the structural adjustment period and the post reform period from 1994 to date.

Between 1970 and 1985, Nigeria's trade policy with reference to agriculture took the form of foreign exchange control, quantitative restrictions and tariffs (Manyong et al., 2005). Two critical instruments defined Nigeria's trade policy, namely, the encouragement of exports of agricultural products via the eradication of export duties on exports crops 
and the eradication or reduction in duties charged on agricultural imports - food, inputs, raw materials, agricultural equipment and machinery (Manyong et al., 2005). While in 1960, the economy experienced moderate trade and payment controls, this was short-lived in the wake of the 1966 crises that birthed the Nigerian Civil War which lasted till 1970. Within this period, there was unprecedented imposition of import licensing and foreign exchange controls. These restrictions and regulations gradually eased after the War.

It would appear that Nigeria's trade policy is driven more by events in the international oil market. A critical analysis (for example Iganiga \& Unemhilin, 2011) shows that liberal trade policies prevail whenever there is an oil boom with attendant increases in oil prices and growth in government revenue. However, import restrictions, foreign exchange and other physical controls assume dominance as soon as the oil boom ends. The government becomes sober (as it were) and inward-looking policies are once again put in place. For instance, benign government revenue occasioned by rising oil prices from 1973 to 1975 ensured a disproportionate increase in imports of relatively cheap foreign agricultural commodities like meat products, wheat flour, rice and vegetable oils. The consequence of this policy was obvious: rising demand for these products due to the lack of competitiveness of local produce further constrained the capacity of domestic producers. This is besides the attendant negative impact on Nigeria's balance of payments position. On the whole, the dominant feature of Nigeria's external trade policy within this period was "the protection of the domestic manufacturing sector at the expense of the agricultural sector" (Manyong et al., 2005).

The unsustainability of Nigeria's rising import bill led to the second cycle of squeeze in trade policy beginning 1977 to 1978 and the subsequent restriction of several imported items. Soon after this period, a second brief boom occurred, with imports again rising to astronomical levels. Nigeria became a dumping ground for all sorts of imported goods, both agricultural and manufactured. However, by the twilight of 1981, an oil glut ensued internationally, oil prices tumbled, government revenues nosedived, the balance of payments position became precarious and government once again introduced import controls in 1982. There was the resurgence of the instrument of import licensing as a means of controlling imports and diversifying the industrial structure of the economy. But this tool was ineffective to achieve diversification because "import licensing coupled 
with an overvalued Naira combined to undermine the quest for the increased export of manufactured goods by unduly cheapening imports and increasing the production cost of export commodities" (Manyong et al., 2005).

Nigeria's trade policy under the SAP period was a general recognition of the obvious failures of state-led strategy to accelerate the pace economic development. With a crippling debt burden, dilapidated and inadequate economic and social infrastructure to initiate any meaningful growth, an over-bloated public sector, a deflated private sector due to a hostile business environment and dwindling government revenue occasioned by falling oil prices, it was apparent that some drastic measures needed to be taken to reverse the drift in the economy. Specifically, trade policy under this phase involved a radical overhaul of the existing tariff structure to protect local industries and domestic production of goods, domestic sourcing of raw materials, import substitution and trade liberalisation. Indeed, Nigeria's trade liberalisation policy as it directly affected the agricultural sector involved the complete dismantling of commodity marketing boards, the abolition of most levies on imports, cuts in some export and excise duties, as well as a reduction by $75 \%$ in the mandatory advance payment of import duties when opening letters of credit (Manyong et al., 2005). There was also the promotion of exports in non-oil goods, especially agricultural commodities. This was achieved by permitting exporters to retain their earnings of foreign exchange in domiciliary accounts with the latitude to freely use the same in their transactions. Finally, there were also measures aimed at substituting imports. The instrument deployed in achieving this was the selective use of import regulations to curtail or outright ban the importation of most food types and raw materials for industries. On the list of banned food items were vegetable oils, maize, barley, wheat and rice. Additionally, there were landing charges of equal value to the excise duties imposed on some domestically made products. The purpose was to improve the price competitiveness of domestic goods.

The new Nigerian Agricultural Policy (NAP) defines Nigeria's agricultural vision in the post-SAP reform era. Within this period was the Agricultural Transformation Agenda (ATA) which spanned 2011 to 2015. While the ATA recorded some significant successes in its brief spell, challenges were both daunting and enduring. For instance, investments in critical agricultural infrastructure (storage facilities, irrigation, roads, warehouses and processing systems) were low, the agricultural import bill, 
estimated at $\$ 3$ billion to $\$ 5$ billion annually, was rising, with an import bill for rice alone exceeding $\$ 1$ billion yearly, etc. (FMARD, 2016). There seems to be no radical difference in Nigeria's trade policy within the NAP framework and other previous policy regimes. Current constraints still remain, "an inability to meet domestic food requirements and an inability to export at quality levels required for market success." Specifically, trade policy still focuses on quantitative restrictions on trade in agricultural products via import and export quotas, tariffs and complete prohibitions. Indeed, under the current Buhari administration, there has been considerable deployment of these tools of outright ban on most agricultural products, mainly rice (FMARD, 2016).

The performance of the Nigerian agricultural sector in terms of value added within the phases discussed above can be summarised in Table 1 . Our brief analysis covers the period 1981-2016, divided into five-year sub-periods. Generally, the table depicts the mixed performance of the agricultural sector. For instance, the share of agriculture in total GDP decreased insignificantly from $35.61 \%$ in Period 1 (1981-1985) to almost $34.2 \%$ in the Period 6. Indeed, from 1981 to 2010, the share of agriculture in total GDP was stable at an average rate of $35 \%$. Sadly, this stable trend was reversed in Period 7 (2011-2016). The same stable and impressive trajectory was noticed in the share of agriculture in non-oil GDP. From an average performance of $42 \%$ in the Period 1, it consistently grew, reaching a peak of almost $58 \%$ in Period 5, before plummeting radically to $29 \%$ in Period 7. Growth rates of the agricultural sector's value added witnessed a substantial increase from $14 \%$ to $26 \%$ (almost 100\%) between 1981-1985 and from 1986-1990. However, this significant improvement in the growth rate of agricultural value added could not be sustained in the succeeding years as it tumbled radically to $13 \%$ before increasing again to about $21 \%$ in Period 4. There was an incredible increase in the growth rate of agricultural value added in Period 5 (2001-2005) amounting to 79\%, but characteristically, this plummeted to $32 \%$ and $20 \%$ in Periods 6 and 7 respectively. Capital expenditure in the agricultural sector indicates a rising trend from over $\mathrm{N} 4$ billion in the Period 1 to over N7 billion in Period 7. 
Table 1: Agricultural Sector Performance

\begin{tabular}{|c|c|c|c|c|c|c|c|}
\hline & Period 1 & Period 2 & Period 3 & Period 4 & Period 5 & Period 6 & Period 7 \\
\hline $\begin{array}{l}\text { Mean GDP } \\
\text { at } 2010 \\
\text { Constant } \\
\text { Factor Cost } \\
\text { (N Billions) }\end{array}$ & $\begin{array}{c}1981 \\
-1985\end{array}$ & $\begin{array}{c}1986 \\
-1990\end{array}$ & $1991-1995$ & $1996-2000$ & $2001-2005$ & $2006-2010$ & $2011-2016$ \\
\hline $\begin{array}{l}\text { Total Agric } \\
\text { GDP }\end{array}$ & $98,747.65$ & $279,073.66$ & $1,443,573.67$ & $5,173,193.57$ & $17,253,495.03$ & $40,139,460.06$ & $105,849,470.8$ \\
\hline Total GDP & $277,327.40$ & $797,802.66$ & $4,361,698.13$ & $15,989,264.83$ & $46,107,804.85$ & $117,518,263.31$ & $499,464,963.58$ \\
\hline $\begin{array}{l}\text { Total non-oil } \\
\text { GDP }\end{array}$ & $230,793.34$ & $554,908.10$ & $2,770,607.41$ & $9,814,432.87$ & $29,985,827.25$ & $76,739,030.47$ & $445,839,965.51$ \\
\hline $\begin{array}{l}\text { Share of } \\
\text { Agric in total } \\
\text { GDP (\%) }\end{array}$ & 35.61 & 35.1 & 33.1 & 32.4 & 37.4 & 34.2 & 21.2 \\
\hline $\begin{array}{l}\text { Share of } \\
\text { Agric in non- } \\
\text { oil GDP (\%) }\end{array}$ & 42.2 & 49.9 & 51.5 & 53.1 & 57.8 & 52.2 & 29.0 \\
\hline $\begin{array}{l}\text { Agric Value } \\
\text { Added }\end{array}$ & 122607 & 157813 & 187745 & 224579 & 396358 & 582096 & 904496 \\
\hline \multicolumn{8}{|l|}{$\begin{array}{l}\text { Agric Value } \\
\text { Added }\end{array}$} \\
\hline $\begin{array}{l}\text { (\% Growth } \\
\text { Rate) }\end{array}$ & 14.12 & 26.14 & 13.37 & 20.8 & 79.4 & 32.56 & 20.54 \\
\hline $\begin{array}{l}\text { Capital } \\
\text { expenditure } \\
\text { on Agric }\end{array}$ & $4,319.66$ & $4,437.56$ & $9,916.86$ & $26,377.04$ & $200,197.94$ & $386,870.73$ & $716,926.00$ \\
\hline $\begin{array}{l}\text { Share of total } \\
\text { labour force } \\
\text { employed in } \\
\text { agriculture } \\
(\%)\end{array}$ & 59.4 & 55.6 & 58.3 & 59 & 57.1 & 46.8 & 35.3 \\
\hline $\begin{array}{l}\text { share of non- } \\
\text { oil exports }\end{array}$ & 71.8 & 77.76 & 70.6 & 57.8 & 30.64 & 44.62 & 43.32 \\
\hline
\end{tabular}

Source: Computed by authors using: CBN Statistical Bulletin (Various Issues); Food and Agricultural Organization (FAO) 2017; World Development Indicators (2017); and National Bureau of Statistics (2017). 
Figure 1: Agriculture value added (\% of GDP)

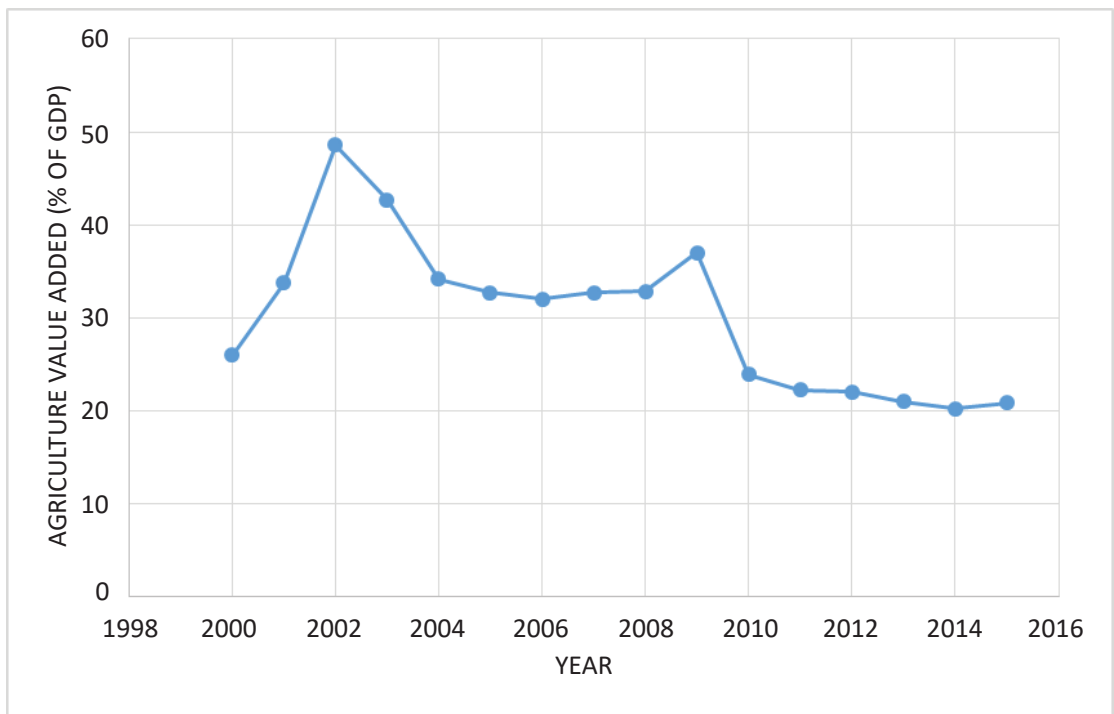

Source: Authors' calculation using data from World Bank (2017).

While the share of agriculture in non-oil exports have been witnessing a downward trend, the total amount of labour employed in the agricultural sector is indicative of the underdeveloped and preponderantly agrarian nature of the Nigerian economy. The sector employs over $50 \%$ of the total labour force, though this share slightly decreased in Periods 6 and 7. Figure 1 crystalises the performance of the percentage share of agricultural sector value added in GDP. Beginning from 2000, its share in GDP rose sharply from $26 \%$ to its peak value of $49 \%$ in 2002 before maintaining a steadily downward slide and stabilizing at an average rate of $33 \%$ in 2008 . There was a marginal increase to $37 \%$ of its share of GDP in 2009, but then a second wave of deterioration ensued from 2010 to 2015 . Within these years, its share in aggregate GDP remained marginal but stable at an average rate of $21 \%$.

\subsection{Infrastructure development and agricultural sector value added}

Nigeria's infrastructure is conceived to encompass several sectors of the economy including transport (with its various subdivisions of roads, rail, 
aviation and water transport), energy, water resources as well as information and communication technology (ICT). Generally, the state of infrastructure in the agricultural sector bears relation to that which obtains in the economy as a whole and has been described with many uncomplimentary epithets, suggestive of the terrible condition in which it presently wallows. For instance, Effiom and Ubi (2016) allude to the twin evils of deficit and decay of Nigeria's infrastructure, especially roads, where they document that as at 2013 the percentage of unpaved roads in Nigeria stood at $81.9 \%$ of total roads; Edame, et al. (2011) contend that perennial conflicting government policies have resulted in the poor state of Nigeria's infrastructure; the Urban Development Bank (2013) as well as Buhari (2000) submit that over $50 \%$ of Nigeria's aggregate road network is in a despicable condition and is attributable to extraordinary low levels of investments in development infrastructure. It is for the above reasons that Sanusi (2012) avers that the financial requirement to fix Nigeria's infrastructure gap would gulp up to $\mathrm{N} 15$ trillion, disaggregated into power N3 trillion, roads and rail N4 trillion and the balance of N9 trillion going into oil and gas. Similarly, the African Development Bank (AfDB, 2014) maintains that Nigeria needs about $\$ 350$ billion over 10 years to execute the provision of the Infrastructure Action Plan (IAP). Yet, Foster and Pushak (2011) argue that for Nigeria to overcome this constraint she must devote $12 \%$ of her GDP over the next decade in infrastructure. In comparison China devoted 15\% of her GDP on infrastructure alone in the 2000s.

But infrastructure provision is a derivative of the commitment to general capital formation in the economy. It is investment or addition to the capital stock that guarantees infrastructure. And in a market driven economy, public sector investment acts as a complement to investment by the private sector. However, the public sector in Nigeria has since the 1970s contributed more than $50 \%$ of gross fixed capital formation (GFCF), with virtually all the established investments going down the drain because of corruption and maladministration (Manyong et al., 2005). Yet, this has not always been the case. In 1963 for instance, the private sector accounted for close to $64 \%$ of Nigeria's GFCF. The dominance of the private sector over domestic investment creation in the country continued until the 1970s when oil revenue took centre stage in Nigeria's revenue profile. With government coffers swelling with petro dollars, large scale public investment in commercial enterprises such as liquefied natural gas facilities, fertilizer, 
aluminium, iron and steel, were established. By 1985, the public sector's share in GFCF stood at $75 \%$. This was a classic case of crowding out of private investment. While this downward trend in the private sector share in domestic investment continued concurrently with inefficiencies in the investments of the public sector, a watershed ensued where the continued relevance of government investments in many projects, generally perceived to belong to the market, was called into question. But to what extent did the agricultural sector benefit from aggregate domestic investment in the economy.

With regards to agricultural investment and infrastructure, Manyong, et al (2005) laments that available data on agricultural investment in Nigeria is limited. Thus, they derive the amount of investment in the agricultural sector indirectly through GFCF. In specific terms, the agricultural sector share in GFCF steadily rose within the years 1981-2000. It rose consistently from 5\% between 1981 to 1985 to about 7\% from 1986 to 1990 and then to about $14 \%$ at the end of 2000. Data constraints mean that we can also analyse agriculture investment indirectly from government capital expenditure on economic services which comprise key sectors of the economy like agriculture, construction, transport and communication and other services. Indeed conceptually, apart from a few strands of infrastructure peculiar only to the agricultural sector, general infrastructure investment in the economy directly influences the performance and output of the agricultural sector. For instance, provision of quality transportation systems (road, rail, aviation and water transportation), education, health, communication, etc. all have direct bearing on the productivity of the agricultural sector. Indeed, agricultural infrastructure is so sweeping that it includes anything which supports agriculture: from fertilizers, transport, electricity systems and communications to seed dealers, irrigation, grain elevators, tractors, cotton gins, insurance and banking services. The Food and Agriculture Organization (FAO, 1996) cited in Pinstrup-Andersen and Shimokawa (2006) submits that "Better communications are a key requirement. They reduce transportation cost, increase competition, reduce marketing margins and in this way can directly improve farm incomes and private investment opportunities". This conclusion is corroborated by different streams of research (see, for instance Fan, Hazell \& Thorat 2000; Mundlak, Larson \& Butzer 2002; Fan, Zhang \& Zhang 2002; Fan \& Zhang 2004). Table 2 and the associated Figure 2 depict government capital investment in economic services, from which we can conveniently infer how the agricultural sector has fared over the years. 
Table 2: Capital and recurrent expenditure on economic services

\begin{tabular}{ccccc}
\hline Year & $\begin{array}{c}\text { Capital } \\
\text { Expenditure on } \\
\text { Economic Services } \\
\text { (N'Billion) }\end{array}$ & $\begin{array}{c}\text { \% of Total } \\
\text { Capital } \\
\text { Expenditure }\end{array}$ & $\begin{array}{c}\text { Recurrent } \\
\text { Expenditure on } \\
\text { Economic Services } \\
\text { (N'Billion) }\end{array}$ & $\begin{array}{c}\text { \% of Total } \\
\text { Capital } \\
\text { Expenditure }\end{array}$ \\
\hline 2000 & 111.51 & 46.57 & 28.59 & 53.43 \\
2001 & 259.76 & 59.21 & 53.01 & 40.79 \\
2002 & 215.33 & 67.00 & 52.95 & 33.00 \\
2003 & 97.98 & 40.54 & 96.07 & 59.46 \\
2004 & 167.72 & 47.75 & 58.78 & 52.25 \\
2005 & 265.03 & 51.02 & 64.31 & 48.98 \\
2006 & 262.21 & 47.47 & 79.69 & 52.53 \\
2007 & 358.38 & 47.20 & 179.07 & 52.80 \\
2008 & 504.29 & 52.48 & 313.75 & 47.52 \\
2009 & 506.01 & 43.89 & 423.61 & 56.11 \\
2010 & 412.20 & 46.64 & 562.75 & 53.36 \\
2011 & 386.40 & 42.07 & 310.50 & 57.93 \\
2012 & 320.90 & 36.69 & 230.10 & 63.31 \\
2013 & 505.77 & 45.63 & 291.23 & 54.37 \\
2014 & 393.45 & 50.24 & 266.40 & 49.76 \\
2015 & 348.75 & 42.62 & 275.36 & 57.38 \\
2016 & 261.28 & 41.16 & 257.73 & 58.54 \\
\hline
\end{tabular}

Source: CBN Statistical Bulletin (2017).

From the table and figure, it is apparent that capital expenditure for economic services of which the agricultural sector is a critical component was consistently higher than its recurrent counterpart over the 16 year period, apart from the singular exception in 2010 and 2016 where the figures were provisional. However, this consistent budgetary allocation to economic services have not had a commensurate impact on the agricultural sector's performance over the same period, for as pointed out above, agriculture value added exhibited mixed trends of poor performance in most of the years. Corroborating this position, FMARD (2016) maintains that the inadequacy or outright absence of agricultural infrastructure has hampered the large-scale development of the sector, scaling up the price of agricultural produce by $50 \%$ to $100 \%$. 
Figure 2: Comparison of recurrent and capital expenditure for economic services

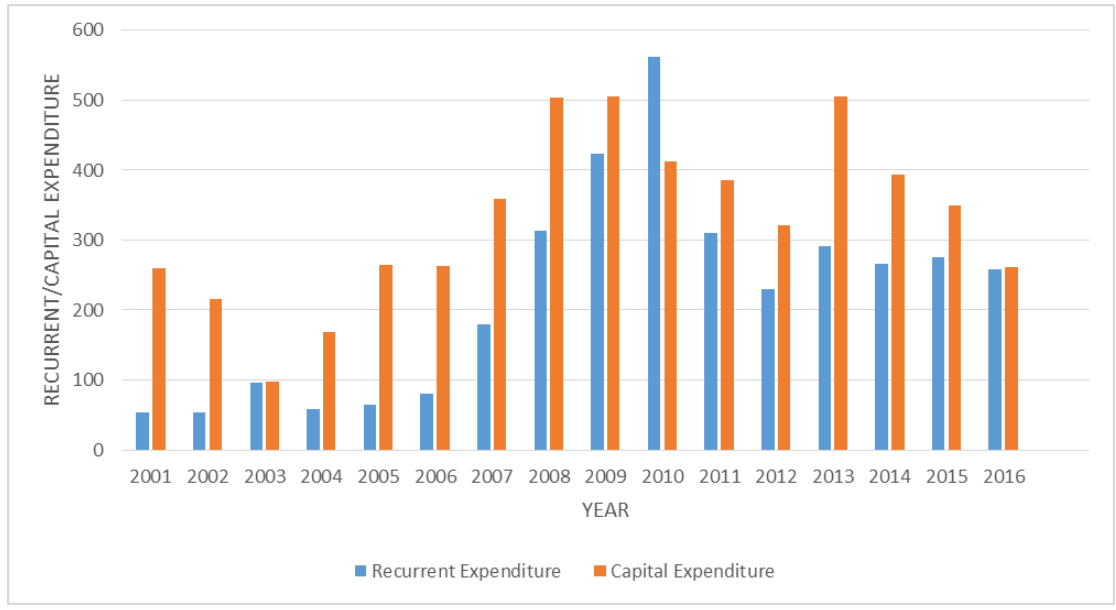

\subsection{Further empirics on agricultural development}

A further review of the literature reveals copious studies dealing with different aspects of agricultural sector performance in Nigeria and developing economies generally. Some of the key themes in the literature relevant to this work are those on agricultural value chain development as well as the effect of macroeconomic policies on agricultural sector growth generally, of which trade policies are a subset. For instance, in evaluating the trends and limitations of some selected macroeconomic policies on Nigeria's agriculture, Olukunle, (2013) found that interest rates, wage rates, exchange rates, as well as agricultural sector expenditure exhibited huge volatilities which inhibited the growth of the sector. In particular, instabilities in these macroeconomic indices ensured a rising cost of agricultural inputs as well as rigidities in loan accessibility, culminating unfortunately to the deprioritisation of the agricultural sector in terms of national sectoral preferences and the lack of competiveness of the sector's products relative to that of other countries in the international market. On a broader scale, Obasaju, Oloni, Obadiaru and Rotimi (2014), in investigating the lessons to be learnt from the implementation of macroeconomic policies in the agricultural sector in developing economies found that emerging economies like India, China and Brazil have leveraged on their respective macroeconomic instruments to develop their agricultural sector. The study 
enjoins other emerging markets to emulate the example of these countries.

With diversification assuming a major theme in development studies, due largely to volatilities in commodity prices of those mono-product economies and attendant negative consequences on government fiscal receipts and capital expenditure, the agricultural sector has once again been the epicentre of focus, because of its capacity to employ a large proportion of the labour force relative to the mining subsector. Thus, Adesoye, Adelowokan, Maku and Salau (2018) investigate the impact of the agricultural value chain on economic diversification in Nigeria. They find that improvement in the agricultural value chain had significant impact on economic diversification in Nigeria. With regards to the development of the value chain in agriculture to aid food production and economic diversification, Kherallah, Camagni and Baumgartner (2015) note that developing countries are bedevilled with institutional and technical constraints which potentially impede their participation in the evolving global agricultural value chain. The study also identifies key drivers for scaling up the involvement of developing economies in the emerging value chain. These are a diverse and heterogeneous set of actors that include governments at various levels, the private sector and the rural people. It emphasises the need for synergy amongst these groups to achieve successful value chain development objectives.

A related study by the Asian Development Bank (ADB, 2012) on value chain development in the agricultural sector finds that the entire architecture and context of value chains are fast changing. This paradigm shift has been mostly procured by reforms in agricultural policies by many countries, leading to the greater participation of the private sector in agriculture development. Urbanisation, increasing incomes and population are related variables that have altered this context. It therefore concludes that though these changes have largely been beneficial to large multinational and national agribusiness firms, small scale agribusinesses and farmers can also participate in the gains by meeting the needs of entrepreneurs and traders. They must address the challenges posed by perishable and/or differentiated products, issues of safety, concerns about the environment, as well as the evolution of retail systems that are comparatively more sophisticated. 


\section{Model and Methodology}

The theoretical anchor to the model specification in this study is briefly reviewed here. Whereas Nigeria's agricultural trade policy may be aptly captured by the classical theory of comparative advantage, the nexus of infrastructure to agricultural value added can be explained by an augmented neoclassical growth theory.

Ricardo (1817) laid the basis of the theory of comparative advantage when he advocated that "under conditions of free trade a country will specialise in the production and export of those commodities it can produce with greatest comparative advantage or least comparative disadvantage, i.e. those commodities it can produce only at lower relative cost". This theory has indeed been the basis of Nigeria's trade policy, given her abundant natural and human resources. With a total area of $923,768 \mathrm{sq} . \mathrm{km}$ disaggregated into land $(910,768 \mathrm{sq} . \mathrm{km})$ and water $(13,000 \mathrm{sq} . \mathrm{km})$ areas, her land supports many cash, staple and food crops all year round. It must be emphasised that out of this aggregate area, the share of agricultural land is $77.7 \%$ (World Bank, 2015). Agricultural land is defined as "the share of land area that is arable, under permanent crops and under permanent pastures". Indeed, the land and vegetation of all the six geo-political zones and their component states are blessed in mineral and natural resources. Discounting petroleum, which has perennially become the dominant foreign exchange earner for the country, the South-South, South-East and South-West geopolitical zones have comparative advantage in the production of cocoa, palm oil, cassava, rice, etc.; the middle belt in yam, fruits, cassava; and the north in groundnut, millet, cucumber, onions, dairy products, beef, etc. Equally in abundance in the country are uranium, coal, limestone, gypsium, bitumen, phosphate, gold, columbite, tantalite and a host of other minerals.

The neoclassical growth theory of Solow (1956) and Swan (1956) specifies a functional relationship between aggregate output in the economy and the inputs necessary to produce it, namely capital, labour and technological progress. An extension and improvement over the HarrodDomar model, the neoclassical model unlike the rigid assumptions of the former, assumes constant returns to scale as well as diminishing returns to the factor inputs, especially capital. A prediction of this model is that poor countries with less abundance of capital will eventually catch up with the rich capitalist countries and that the latter would arrive at a steady state 
where further growth would be stalled. It is this inevitability of secular stagnation that poses a major criticism of the theory, for it implies that the economy cannot grow beyond a certain point in spite of increases in the investment rate of physical capital. In other words, accounting for both capital and labour as sources of long-run growth, the model cannot explain what causes technological progress, the only factor unrestricted from the burden of diminishing marginal returns. Beginning with the Cobb-Douglas production function, we have,

$$
\mathrm{Y}=f\left(A K^{a} L^{1-a}\right)
$$

Where $Y$ is aggregate output in the economy; $K$ is capital, $L$ is labour and $A$ is technological progress or total factor productivity. Though $\mathrm{Y}$ is economy-wide output, in this study following Ada \& Anyanwu (2013), Ogbuagu and Udo (2012), Adebiyi \& Dauda (2004) and Lucas (1988), we deploy the aggregate production function above to model a subset of the economy, namely, the agricultural sector. The flexibility of the Cobb-Douglas production function allows for augmentation and the incorporation into A of other factors that specifically influence the output of the agricultural sector. Trade policy in Nigeria is proxied by the degree of openness of the economy, measured by the ratio of the sum of import and exports to the GDP. A number of measures for infrastructure are deployed in this study. These include electric power consumption, mobile cellular subscriptions and rail lines. Interest and exchange rates also enter the model as critical determinants of agricultural sector investment in Nigeria.

Thus $A$ in equation (1) becomes:

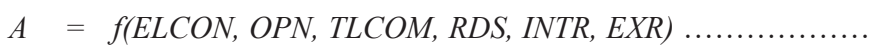

Substituting equation (2) into (1), the functional form of the model is:

$Y=f(E L C O N, O P N, T L C O M, R D S, I N T R, E X R, K, L) \ldots \ldots \ldots \ldots \ldots$ 
Recalling that $Y$ is agricultural sector productivity, equation (3) transforms into linearised econometric model of the form:

$$
\begin{aligned}
\ln A V D= & \delta_{0}+\delta_{1} \ln E L C O N+\delta_{2} O P N+\delta_{3} \ln T L C O M+\delta_{4} \ln R D S+\delta_{5} I N T \\
& +\delta_{6} E X R+\delta_{7} \ln K+\delta_{8} \ln L+\mu \ldots .
\end{aligned}
$$

Where

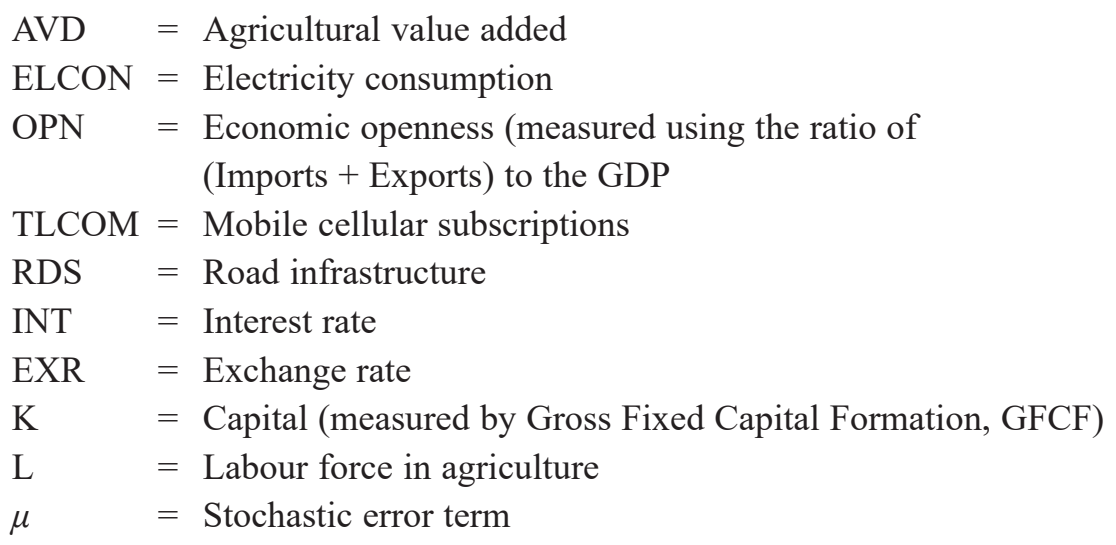

The study adopts the descriptive and quantitative method of analysis. The quantitative method of analysis is based on the use of the Dickey-Fuller Min-t test and the Autoregressive Distributed Lag (ARDL) model/Bounds test of (Pesaran, Smith and Shin, 2001). The latter method was preferred because of the stationarity properties of the time series data which exhibited admixture of stationary series at levels and those stationary after their first difference. Several advantages accrue from the use of the ARDL technique. First, Ghatak and Siddiki (2001) maintain that it is the most useful method in determining cointegration in small sample sizes; second, it obviates the need (often required in other techniques) of the series to be of the same order of integration and lastly it provides unbiased long-run estimates with the endogenous regressors (Ogbuagu \& Udo, 2012; Udah, 2010). Consequently, equation (4) can be transformed into the ARDL model of the form: 


$$
\begin{aligned}
& \Delta \Lambda V D_{t}=c_{0}+\delta_{1} \Lambda V D_{t-1}+\delta_{2} \operatorname{lnELCON}_{t-1}+\delta_{3} O P N_{t-1}+\delta_{4} \operatorname{lnTLCOM} \operatorname{Co}_{t-1}+\delta_{5} \ln R D S_{t-1} \\
& +\delta_{6} I N T_{t-1}+\delta_{7} E X R_{t-1}+\delta_{8} \ln K_{t-1}+\delta_{9} \ln L_{t-1}+\sum_{i=0}^{k} \lambda_{1} \Delta A V D_{t-1} \\
& +\sum_{i=0}^{k} \lambda_{2} \Delta \ln E L C O N_{t-1}+\sum_{i=0}^{k} \lambda_{3} \Delta O P N_{t-1}+\sum_{i=0}^{k} \lambda_{4} \Delta \ln T L C O M_{t-1} \\
& +\sum_{i=0}^{k} \lambda_{5} \Delta \ln R D S_{t-1}+\sum_{i=0}^{k} \lambda_{6} \Delta I N T_{t-1}+\sum_{i=0}^{k} \lambda_{7} \Delta E X R_{t-1}+\sum_{i=0}^{k} \lambda_{8} \Delta \ln K_{t-1} \\
& +\sum_{i=0}^{k} \lambda_{9} \Delta l n_{t-1}+\mu
\end{aligned}
$$

The ARDL model above is disaggregated into the long-run and shortrun components, with $\delta_{1}$ to $\delta_{9}$ being the long-run multipliers, while the $\mathrm{c}$ is the intercept and $\mu$ the error term. The ARDL proceeds with an initial determination of the existence or otherwise of a long-run relationship among the variables. If they are cointegrated, the long-run and short-run models are estimated respectively. Table 3 presents measurements of the study variables as well as their sources. The study period covered 1981 to 2016.

Table 3: Variable measurement and data sources

\begin{tabular}{lll}
\hline \multicolumn{1}{c}{ Variables } & \multicolumn{1}{c}{ Measurements } & \multicolumn{1}{c}{ Data Sources } \\
\hline AVD & Agriculture Value Added & World Bank (2017) \\
ELCON & Electricity Consumption & World Bank (2017) \\
OPN & $\begin{array}{l}\text { Economic Openness (measured using } \\
\text { the ratio of Imports + Exports to }\end{array}$ & World Bank (2017) \\
& GDP) & \\
TLCOM & Mobile Cellular Subscriptions (per & World Bank (2017) \\
& 100 people) & \\
RDS & Road Transport share as a \% of GDP & CBN Statistical Bulletin, 2017 \\
INT & Real Interest Rate & CBN Statistical Bulletin, 2017 \\
EXR & Real Exchange Rate & World Bank (2017) \\
K (GFCF) & Stock of GFCF (\% of GDP) & World Bank (2017) \\
LAB & Labour Force in Agriculture & World Bank (2017) \\
\hline
\end{tabular}




\section{Presentation of Results}

Table 4: Unit root test result

\begin{tabular}{|c|c|c|c|c|c|c|}
\hline \multirow{2}{*}{ Variables } & \multicolumn{2}{|c|}{$\begin{array}{l}\text { ADF Statistics } \\
\text { (Computed) }\end{array}$} & \multirow{2}{*}{ Remark } & \multicolumn{2}{|c|}{$\begin{array}{c}\text { Philips-Perron (PP) } \\
\text { Test }\end{array}$} & \multirow{2}{*}{ - Remark } \\
\hline & Level & $\begin{array}{c}1^{\text {st }} \\
\text { Difference }\end{array}$ & & Level & $\begin{array}{c}1^{\text {st }} \\
\text { Difference }\end{array}$ & \\
\hline AVD & -1.231158 & -5.713696 & $1(1)$ & -1.225717 & -5.712526 & $\mathrm{I}(1)$ \\
\hline ELCON & -2.545347 & -7.501703 & $1(1)$ & -2.607712 & -7.898092 & $\mathrm{I}(1)$ \\
\hline EXR & -1.798966 & -3.972592 & $1(1)$ & -1.561594 & -3.899442 & $\mathrm{I}(1)$ \\
\hline GFCF & -3.017426 & -5.692858 & $1(1)$ & -3.905617 & - & $\mathrm{I}(0)$ \\
\hline INTR & -6.272095 & - & $1(0)$ & -6.372726 & - & $\mathrm{I}(0)$ \\
\hline LAB & -2.270882 & -3.691272 & $1(1)$ & -2.228361 & -3.554911 & $\mathrm{I}(1)$ \\
\hline OPN & -3.199633 & -5.053272 & $1(1)$ & -3.185949 & -8.993499 & $\mathrm{I}(1)$ \\
\hline RDS & -2.496645 & -5.396741 & $1(1)$ & -2.439084 & -5.403736 & $\mathrm{I}(1)$ \\
\hline TLCOM & -1.851703 & -10.82060 & & -0.172354 & -3.582437 & $\mathrm{I}(1)$ \\
\hline
\end{tabular}

Critical ADF value at level: $5 \%=-3.544284$

Critical ADF value at 1st Diff: $5 \%=-3.548490$

Critical PP value at level: $5 \%=-3.544284$

Critical PP value at 1 st Diff: $5 \%=-3.548490$

Source: Authors' computation.

Table 4 presents the results of the unit roots of the data used for the study. Two conventional approaches were adopted. First, we employed the Augmented Dickey Fuller (ADF) technique on the series, while the Philips Peron (PP) was used for confirmation. The results reveal that for the ADF, the entire series was integrated of I(1), except interest rate which was stationary at levels. In other words, the underlying macro data were nonstationary at their levels but became stationary after first difference. While the PP test confirmed most of the conclusions of the ADF test, it further revealed a better result for GFCF, namely that it was stationary at level. Thus, a combination of a series integrated of different orders, as in this case, provides the justification of the choice of the ARDL analytical technique. Table 5 presents results of the Bounds test results aimed at establishing the existence or otherwise of any cointegrating relationship among the model variables. 
Table 5: ARDL Bounds test result

\begin{tabular}{lcc}
\hline Test Statistic & Value & K \\
\hline F-statistic & 8.074619 & 7 \\
\hline Critical Value Bounds & & \\
\hline Significance & I0 Bound & I1 Bound \\
\hline $10 \%$ & 2.03 & 3.13 \\
$5 \%$ & 2.32 & 3.5 \\
$2.5 \%$ & 2.6 & 3.84 \\
$1 \%$ & 2.96 & 4.26 \\
\hline
\end{tabular}

Source: Authors' computation.

Results indicate that we must reject the null hypothesis of absence of cointegration amongst the variables, as the estimated F-statistic of 8.07 is higher than the critical values at both the lower and upper bounds at all levels of significance provided in Pesaran et al. (2001). With a long-run cointegrating relationship established, we then estimated both the short-run error correction model as well as its long-run cointegrating form.

Table 6: Result of long-run ARDL model

Dependent Variable: LOG (AVD)

\begin{tabular}{lcccc}
\hline \multicolumn{1}{c}{ Variable } & Coefficient & Std. Error & t-statistic & Prob. \\
\hline LOG(ELCON) & -1.455954 & 0.286118 & -5.088647 & 0.0070 \\
LOG(EXR) & 0.066491 & 0.008561 & 7.766437 & 0.0162 \\
GFCF & 0.000430 & 0.000613 & 0.700676 & 0.5560 \\
INTR & 0.109425 & 0.006598 & 16.58493 & 0.0036 \\
LOG(LAB) & 7.137254 & 2.067151 & 3.452700 & 0.0260 \\
TLCOM & 0.018287 & 0.005248 & 3.484190 & 0.0253 \\
RDS & -1.814559 & 0.827387 & -2.193120 & 0.0934 \\
OPN & -0.966010 & 0.573615 & -1.684075 & 0.2342 \\
C & -92.484355 & 32.925085 & -2.808933 & 0.0484 \\
\hline
\end{tabular}

Selected Model: ARDL(1, 3, 3, 3, 3, 2, 3, 3,3)

Source: Authors' computation. 
The estimated long-run ARDL model is presented in Table 6. Consistent with theory, GFCF, LAB and TLCOM, turned out with the right positive sign, indicating that agricultural value added is an increasing function of these variables. However, the signs of the estimated coefficients of ELCON, INTR, EXR and RDS turned out wrong signs that were inconsistent with theoretical postulations; they were however statistically significant. Equally worth emphasising is the fact that electricity consumption, LAB and RDS, similar to the result of the short-run error correction model, were significant variables influencing agricultural value added in Nigeria. Nigeria's trade policy measured by OPN turned out to have both a negative and insignificant impact on agricultural value added. We next discuss the short-run error correction results of our selected ARDL model.

Table 7 presents results of the selected short-run ARDL model. Mixed outcomes are observed for the lags of respective variables. For instance, while the current level of electricity consumption is positively and significantly related to agricultural value added, conforming with theory, its first and second lags have negative relation with agricultural value added, with statistical significance recorded for the second lag. Mixed results are also observed for exchange rate. While both current and lagged estimated coefficients of exchange rate meet theoretical expectations, showing that a rise in exchange rate deteriorates agricultural productivity since most farm inputs are imported, only the second lag of the first difference of exchange rate is statistically significant. Similarly, GFCF, a proxy for physical capital investment, indicates robust positive and significant relation with the dependent variable in its current and second lags. It means that previous levels of investment are significant in explaining improvements in agricultural sector value added. The estimated coefficient of interest rates are all consistent with theory. Nonetheless, it is only its second lag that is significant. The current and first lagged estimates of labour reveal contradictory effects on agricultural value added. While the former bears a direct but insignificant relationship with the dependent variable, consistent with theory, the latter though significant at the $10 \%$ level is contrary to a priori expectations. 
Table 7: Error correction representation of the selected ARDL model

Dependent Variable: LOG (AVD)

\begin{tabular}{|c|c|c|c|c|}
\hline Variable & Coefficient & Std. Error & t-statistic & Prob. \\
\hline DLOG(ELCON) & 0.470558 & 0.144109 & 3.265301 & 0.0309 \\
\hline DLOG(ELCON(-1)) & -0.425092 & 0.338809 & -1.254664 & 0.2779 \\
\hline DLOG(ELCON(-2)) & -0.942342 & 0.267091 & -3.528165 & 0.0243 \\
\hline DLOG(EXR) & -0.120352 & 0.060387 & -1.993026 & 0.1170 \\
\hline DLOG(EXR(-1)) & -0.044468 & 0.040713 & -1.092245 & 0.3361 \\
\hline DLOG(EXR(-2)) & -0.171134 & 0.045800 & -3.736560 & 0.0202 \\
\hline $\mathrm{D}(\mathrm{GFCF})$ & 0.066200 & 0.018897 & 3.503145 & 0.0248 \\
\hline $\mathrm{D}(\mathrm{GFCF}(-1))$ & -0.013306 & 0.013608 & -0.977835 & 0.3835 \\
\hline $\mathrm{D}(\operatorname{GFCF}(-2))$ & 0.026331 & 0.005864 & 4.490544 & 0.0109 \\
\hline D(INTR) & -0.003135 & 0.001609 & -1.948108 & 0.1232 \\
\hline D(INTR(-1)) & -0.001177 & 0.000931 & -1.263521 & 0.2750 \\
\hline D(INTR(-2)) & -0.003904 & 0.001559 & -2.504259 & 0.0665 \\
\hline DLOG(LAB) & 0.145580 & 0.898524 & 0.162021 & 0.8791 \\
\hline DLOG(LAB(-1)) & -3.073619 & 1.129820 & -2.720449 & 0.0530 \\
\hline D(TLCOM) & 0.054467 & 0.025093 & 2.170589 & 0.0257 \\
\hline D(TLCOM(-1)) & 0.090209 & 0.030686 & 2.939721 & 0.0424 \\
\hline $\mathrm{D}(\mathrm{TLCOM}(-2))$ & 0.029329 & 0.021056 & 1.392947 & 0.2361 \\
\hline $\mathrm{D}(\mathrm{RDS})$ & -0.028904 & 0.005728 & -5.046241 & 0.0073 \\
\hline $\mathrm{D}(\operatorname{RDS}(-1))$ & -0.018024 & 0.007179 & -2.510664 & 0.0260 \\
\hline $\mathrm{D}(\mathrm{RDS}(-2))$ & -0.028904 & 0.005728 & -5.046241 & 0.0073 \\
\hline $\mathrm{D}(\mathrm{OPN})$ & -0.001805 & 0.000700 & -2.577781 & 0.0615 \\
\hline $\mathrm{D}(\mathrm{OPN}(-1))$ & 0.001163 & 0.000925 & 1.256147 & 0.2774 \\
\hline CointEq(-1) & -0.942342 & 0.267091 & -3.528165 & 0.0043 \\
\hline \multicolumn{5}{|c|}{ Selected Model: ARDL $(1,3,3,3,3,2,3,3)$} \\
\hline \multicolumn{5}{|c|}{ Breusch-Godfrey Serial Correlation LM Test: F-statistic - 0.351464 Prob (0.6469) } \\
\hline \multicolumn{5}{|c|}{ Ramsey RESET Test: F-statistic - 1.640574. Prob. (0.1705) } \\
\hline
\end{tabular}

Source: Authors' computation.

Developments in information and communications technology (ICT) represented by TLCOM reveal a positive and significant relationship with agricultural value added in its current and first lag. It was however insignificant though positively related with agricultural productivity in the second lag. A significant observation from the result is the effect of roads 
infrastructure (RDS) on the agricultural value added. Results indicate that road infrastructure is a significant factor influencing the performance of the agricultural sector; however, all estimated coefficients across the lagged period revealed a negative relationship. Similarly, another key policy variable of the study shows mixed results: the first difference of OPN indicates a negative and significant relationship with the dependent variable at the $10 \%$ significance level, while the first lag reveals a positive but insignificant correlation with agriculture value added. Finally, the error correction term was negative and significant and also indicated a strong speed of adjustment of $94 \%$ to long-run equilibrium.

Several post-estimation tests were conducted to ascertain the validity and reliability of our model. We tested for the linearity of the model by employing the Ramsey Reset test which produced an insignificant probability value of 0.471 , indicating that the empirical model is correctly specified. Serial autocorrelation was tested using the Breusch-Godfrey Serial Correlation LM Test as well as the Q-statistic test. The calculated F-statistics of these tests were all insignificant, indicating model stability and relevance for forecasting and policy purposes.

\section{Discussion of Findings}

We limit our discussion of results to the key policy variables of our study, namely infrastructure (electricity consumption, roads, telecommunications) and trade policy. First, we note that the error term of our selected ARDL model was both negative and significant at the $1 \%$ level. A high speed of adjustment of $94 \%$ means that short run shocks are quickly corrected to their long-run equilibrium values. We also note that electricity consumption in the current period was positively and significantly correlated with agricultural value added. But this positive correlation was not sustained in subsequent periods. A plausible reason for this is not far-fetched. Electricity supply in Nigeria has been a subject of national embarrassment over many decades now. Frequent power outages, operational inefficiencies and mismatch between electricity generation and transmission have been the defining aspects of Nigeria's power sector. For instance, average capacity utilisation in the sector in the last 40 years has been less than $40 \%$; generation capacity was about $3000 \mathrm{MW}$, roughly thrice the current level of national demand (Emeka et al., 2016; Ubi, Eke \& Oduneka, 2011). Currently, Nigeria has 
12.5 GW of installed capacity, but less than one-third is operational, with only about $15 \%$ of installed capacity eventually distributed to consumers (Ministry of Budget and National Planning, 2017). Indeed, in the 2000s, electricity consumption per capita deteriorated. Power outages occur more than 320 days in a year, a frequency which exceeds other African countries (Foster \& Pushak, 2011). These negative trends guarantee the economy's dependence on power-generating units. Sadly, in 2014 alone, Nigeria imported an aggregate of 28,678 generators worth over N40.8 billion or $\$ 185.5$ million, the second biggest market for generators after Egypt (PowerGen Statistics, 2015). This dismal negative short-run relationship between electricity consumption and agricultural value added reflects aggregately on the long-run results which shows that though electricity consumption is a significant factor influencing agricultural value added, the relationship is nonetheless inconsistent with theory (see, for instance: Fan et al., 2000; Mundlak et al., 2002; Fan et al., 2002; Fan \& Zhang, 2004).

Road and telecommunications infrastructure are yet other critical elements in overall infrastructure requirements for agricultural value added. Mixed outcomes of estimated coefficients of these variables re-echo the parlous state of our roads, in particular. The estimated coefficients of roads across the respective lags show a negative but significant relationship with agricultural value added. Agricultural activities are majorly domesticated in rural areas controlled by sub-national governments and local government authorities and yet according to Foster and Pushak (2011), "Problems of road maintenance are apparently much more severe at the sub-national level... Even more worrisome is the fact that only $33 \%$ of unpaved roads are in good or fair condition". And these have consequences for the pricing, storage and quality of agricultural produce. The problems persist because of underfunding of road maintenance activities in Nigeria. Out of a benchmark requirement of $\$ 240$ million, only $\$ 50$ million is earmarked for preventive maintenance (Foster \& Pushak, 2011).

There can be no understating the multiplier effects brought about by ICT revolution in Nigeria since 2001 when Nigeria joined the global system of mobile communications (GSM). Foreign direct investment in this sector has been steadily rising with Nigeria attracting more than $50 \%$ of the $\$ 28$ billion private capital invested in the sector, not to mention employment generation as well as greater efficiency in business operations in the economy. Studies show that all urban areas in Nigeria are fully covered with GSM signals, 
while more than half of the population in rural areas have signals within their reach. In tandem with economic realities on the ground, our results indicate a positive and significant impact of telecommunications on agriculture value added both in the short and long-runs. The estimated coefficient of the second lag of telecommunications was however insignificant. This may be suggestive of the persistent challenges facing the sector which have invariably rubbed off on the performance of the agricultural sector. For instance, the lack of electricity infrastructure in most rural areas compromise the efficiency of GSM operators, while the cost of accessing the internet remains high for most Nigerians. Thirdly, there has been the perennial occurrence of poor network connectivity, dropped calls, as well as hidden charges by operators. Of significance is the fact that a greater segment of the labour force in the Nigerian agricultural sector is illiterate, lacking in skills and hampered by cultural prejudices in the use of various components of ICT (Posu, 2006).

Nigeria's liberal trade policies since the mid-1980s have brought more harm than good on the economy and on the agricultural sector in particular (Ndebbio, 2006; Oyefusi \& Udoh, 2004). With the abolition of import licensing, commodity boards and a regulated exchange rate regime, our exports (majorly primary agricultural produce) competed on the same level with foreign products. With a rising cost of inputs due to increases in the exchange rate, there was a general productivity squeeze in the economy; cheap and better-quality foreign goods were preferred to locally produced ones. This was a huge disincentive to agricultural productivity. Indeed, our results resonate with this scenario. In the long-run, agricultural value added is a decreasing function of trade policy (OPN). Worse still, it turned out to be an insignificant variable influencing the performance of the agricultural sector. In simple terms, our agricultural sector was worse off within the trade policy regime adopted by Nigeria, primarily due to weak domestic productive capacity. The short-run results reflect this conclusion also. Several empirical studies affirm the above observed trends of the agricultural sector's dismal performance in relation to trade policy. Eyo (2008) for instance, assesses the agricultural sector's effect of macroeconomic policies and finds that the exchange rate regime (a component of trade policy) adopted overtime was a huge disincentive to the sector's performance. Similarly, Colmen and Okorie (1998) had earlier documented that the trade and foreign exchange management policies of the structural adjustment programme had 
adverse consequences on agricultural exports in Nigeria. However, Inusa, Daniel, Dayagal and Chiya (2016) came to a different conclusion concerning the effect of the exchange rate on agricultural output in Nigeria. They affirm that the exchange rate positively and significantly influenced agricultural sector performance. See also Aroriode and Ogunbadejo (2014) for similar conclusions.

Our results also revealed that in the long-run aggregate capital investment in the economy represented by GFCF was not a significant factor influencing performance of the agricultural sector. This is not surprising as government expenditure has been skewed in favour of recurrent expenditure to the neglect of building productive capacity in the economy and therefore impacting marginally on the economy (Olorunleke \& Alimi, 2013, cited in Oladipo \& Ayegbusi, 2016).

\section{Conclusion and Recommendations}

The collapse of the international price of crude oil in 2015 and its attendant negative consequences on government fiscal capacity and development efforts re-echoed the need for Nigerians to return to agriculture as it was in the days of the First Republic. While government revenue dwindled in the wake of the oil crises, Nigeria's liberalised trade policy fuelled her perennial appetite for imports, with foreign reserves used to finance the country's current account deficit. It was within this context that this paper undertook to empirically quantify and establish the nexus between agricultural value added, infrastructure and Nigeria's trade policies. Our burden for this study stemmed from noticeable gaps in the literature, namely, that most extant studies focus more on agricultural productivity measured by the contribution of the agricultural sector to the GDP. But productivity gains in agriculture can only come through its value added and not just expansions of cultivatable land. Besides, there is the rarity of empirically linking trade policy to infrastructure in order to gain insight into the effect of their dynamic interactions on agricultural value added. Rather, what subsists in the literature is the treatment of these variables in isolation of each other.

The result of our empirical analysis concurs with the historical developments and realities of the Nigerian agricultural sector, nay, the economy. Our recommendations are directed to the key policy variables of the study. Infrastructure is the aggregate resource system that forms 
the productive substructure of the economy. It is a key driver to private sector investment and agricultural sector development in particular. First, government at all levels must, through its various agencies like the Federal Emergency Road Maintenance Agency (FERMA), federal and state ministries of works and housing, renew their commitment to the provision of road infrastructure. Subnational governments in particular are burdened more with this responsibility as most farmers and agricultural land is in rural communities with deplorable road conditions. This might require more funds to be allocated to road maintenance and construction of new ones. Equally important is the need to plug leakages in public sector funds allocated to infrastructure so as to derive value for money on these projects. The same goes for electric power, another critical element in the infrastructure chain. Electricity has positive spill overs on virtually all other sectors of the economy. Happily, a large chunk of infrastructure requirements is currently domiciled in one ministry, the Ministry of Power, Works and Housing. We strongly advocate that the government studies and implements the report of the African Development Bank (AfDB, 2014) infrastructure action plan for Nigeria.

Similarly, the Nigerian Communications Commission (NCC) should live up to its responsibility as the agency that oversees the telecommunications industry. While there is considerable growth in this sector, challenges identified above still persist. Generally, beyond making and receiving of calls, the vast majority of mobile phone users are ignorant of many other benefits derivable from their mobile devices. ICT providers can initiate public enlightenment programmes in the rural communities to help educate the mass of local people, especially farmers, on how to use mobile phones and the attendant benefits to their occupation.

Trade policies still matter to an economy that desires growth and development. Besides the static gains generated from liberal trade regimes, other dynamic and more permanent benefits of trade have been documented. In view of the underdevelopment of Nigeria's agricultural sector, the study recommends that the current ban on some selected food items should be consolidated, without which Nigeria would continue to be a net food importer when indeed, with determined political will, her vast arable land, "diversified ecological zones, abundant water resources and adequate rainfall in most regions of the country" can be exploited to bring economic prosperity to her people. We advocate guided trade liberalisation wherein 
while embracing the principles of conventional trade liberalisation, the government properly articulates the weakness of the economy's productive structure and encourages farmers and local producers to attain maturity. It is a welcome development that there is a significant improvement in the capacity of our local rice production. This could not have been possible if the nation's borders were left open for the influx of cheap foreign rice.

Further space for research exists in this area, as the present effort is by no means exhaustive. It is hereby suggested that future research efforts could be directed in a more disaggregated manner to investigating the impact of trade policy on the different components and segments of the agricultural sector namely, crop production, livestock production, fisheries, etc. Furthermore, an analysis of the macroeconomic policy impact on agricultural value chains in Nigeria might be another veritable focus for future research.

\section{References}

Ada, A.M. \& Anyanwu, S.O. (2013). Institutional reforms and agricultural sector performance in Nigeria. Selected Papers from the 2013 Annual Conference of Nigerian Economic Society (NES), Nigerian Economic Society, 289-314.

Adebiyi, M.A. \& Dauda, R.O.S. (2004). Trade liberalization policy and industrial growth performance in Nigeria: An error correction mechanism (ECM) technique. Selected Papers for the 2004 Annual Conference of Nigerian Economic Society (NES), Nigerian Economic Society, 119-145. Adesoye, B. A., Adelowokan, O. A., Maku, E.O. \& Salau, S.O. (2018). Enhancing agricultural value chain for economic diversification in Nigeria. African Journal of Economic Review, VI (I), 103-118.

AfDB Group (2014). An Infrastructure Action Plan for Nigeria: Closing the infrastructure gap and accelerating economic transformation. Retrieved from: https://www.afdb.org/en/documents/document/an-infrastructureaction-plan-for-nigeria-closing-the-infrastructure-gap-and-acceleratingeconomic-transformation-33031

Ajudua, E.I. \& Davis, J.P. (2015). A review of monetary policy and the Nigerian agricultural sector performance. International Journal of Academic Research in Progressive Education and Development. 4(3), 70-86. DOI: 10.6007/IJARPED/v4-i3/1789

Anowor, O. F., Ukweni, N. O. \& Martins, I. (2013). The impact of trade 
liberalisation on Nigeria agricultural sector. Journal of Economics and Sustainable Development, 4(8), 14-24.

Aroriode, O.R. \& Ogunbadejo, H.K. (2014). Impact of macroeconomic policy on agricultural growth in Nigeria. IOSR Journal of Agriculture and Veterinary Science, 7(11), 1-5.

Asian Development Bank (2012). Support for agricultural value chain development. Retrieved from: https://www.adb.org/sites/default/files/ evaluation-document/35898/files/eks-agriculturalvaluechain.pdf

Buhari, M. (2000). The role of infrastructural development and rehabilitation in sustainable economic growth in Nigeria. Paper presented at the All Peoples Party Economic Summit held at Ladi Kwali Conference Centre, Sheraton Hotel and Towers Abuja, $9^{\text {th }}-10^{\text {th }}$ November. Retrieved from: http://www.anppusa.org/

Central Bank of Nigeria (2017). Statistical Bulletin. Retrieved from: https:// www.cbn.gov.ng/documents/statbulletin.asp

Chete, L. N., Adeoti, J. O. F., Adeyinka, M. \& Ogundele, O. (2014). Industrial development and growth in Nigeria: Lessons and challenges. Learning to Complete. Working Paper No. 8. Nigerian Institute of Social and Economic Research (NISER), Ibadan.

Colmen, D. \& Okorie, A. (1998). The effect of structural adjustment on the Nigerian agricultural export sector. Journal of International Development, 10(3), 341-355. DOI: 10.1002/(SICI)1099-1328 (199805/06)10:3<341::AID-JID453>3.0.CO;2-8

Edame, G. E., Fonta, W. M., Edet, E. O. \& Henshaw, V. E. (2011). Public expenditure, infrastructure and industrial growth drivers in Nigeria: A vector auto error correction specification. In E. Udoh, U. R. Ogbuagu \& U. Essia (Eds.), Port Harcourt, Nigeria: Industrial Development: A Catalyst for Rapid Economic Growth (pp. 151-170). P. N. Davidson Publications.

Effiom, L. \& Ubi, P.S. (2016). Deficit, decay and de-prioritization of transport infrastructure in Nigeria: Policy options for sustainability. International Journal of Economics and Finance, 8(3) 55-68.

Emeka, A., Igberi, C.O., Udude, C.C. \& Odo, S.I. (2016). Power supply, average manufacturing capacity utilization and unemployment in Nigeria. Asian Research Journal of Arts \& Social Sciences, 1(2), 1-15. DOI: $10.9734 / A R J A S S / 2016 / 27683$

Eyo, E. O. (2008). Macroeconomic environment and agricultural sector 
growth in Nigeria. World Journal of Agricultural Sciences, 4(6), 781786.

Fan, S. \& Zhang, X. (2004). Infrastructure and regional economic development in rural China. China Economic Review, 15, 203-214. https://doi.org/10.1016/j.chieco.2004.03.001

Fan, S., Hazell, P. \& Thorat, S. (2000). Government spending, growth and poverty in rural India. American Journal of Agricultural Economics, 82(4), 1038-1051. https://doi.org/10.1111/0002-9092.00101

Fan, S., Zhang, L. \& Zhang, X. (2002). Growth, inequality and poverty in rural China: The role of public investments. International Food Policy Research Institute Research Report 125. https://www.ifpri.org/ publication/growth-inequality-and-poverty-rural-china-role-publicinvestments

FMARD (2016). The agriculture promotion policy (2016 - 2020): Building on the successes of the ATA, closing key gaps. Policy and Strategy Document of the Federal Ministry of Agriculture and Rural Development. Retrieved from: http://nssp.ifpri.info/files/2017/12/2016Nigeria-Agric-Sector-Policy-Roadmap_June-15-2016_Final.pdf

Foster \& Pushak (2011). Nigeria's infrastructure: A continental perspective. A publication of the World Bank. Retrieved from: https://ppiaf.org/ documents/3154/download

Ghatak, S. \& Siddiki, J. (2001). The use of ARDL approach in estimating virtual exchange rates in India. Journal of Applied Statistics, 11, 573583. DOI: $10.1080 / 02664760120047906$

Iganiga, B.O. \& Unemhilin, D.O. (2011). The impact of federal government agricultural expenditure on agricultural output in Nigeria. Journal of Economics, 2(2), 81-88, http://doi.org/10.1080/09765239.2011.11884939

Inusa, B. M., Daniel, P.C., Dayagal, D.F. \& Chiya, N.S. (2016). Nigerian economic growth and recovery: Role of agriculture. International Journal of Economics \& Management Sciences, 7(2), 512-523, DOI: 10.4172/2162-6359.1000512

Kherallah, M., Camagni, M. \& Baumgartner, P. (2015). Sustainable inclusion of smallholders in agricultural value chains. A publication of International Fund for Agricultural Development (IFAD). Retrieved from: https:/www.ifad.org/documents/38714170/40264252/ Scaling + up + note +-+ Sustainable + inclusion + of + smallholders + in + agricu ltural+value+chains.pdf 
Lucas, R.E. (1988). On the mechanics of economic development. Journal of Monetary Economics, 22, 3-42.

Manyong, V.M., A. Ikpi, J.K. Olayemi, S.A. Yusuf, B.T. Omonona, V. Okoruwa \& F.S. Idachaba (2005). Agriculture in Nigeria: Identifying opportunities for increased commercialization and investment. Ibadan, Nigeria: IITA.

Michael, E.O. (2017). Agricultural sector performance and Nigeria's economic growth. Asian Journal of Agricultural Extension, Economics \& Sociology, 15(1), 1-13. DOI: 10.9734/AJAEES/2017/31828

Ministry of Budget and National Planning (2017). Nigeria Economic Recovery and Growth Plan, 2017-2020. Retrieved from: https:// nigeriaembassygermany.org/mosaic/_M_userfiles/Economic-RecoveryGrowth-Plan-2017-2020.pdf

Muftaudeen, O. O. \& Hussainatu, A. (2014). Macroeconomic policy and agricultural output in Nigeria: Implications for food security. American Journal of Economics, 4(2), 99-113. DOI: 10.5923

Mundlak, Y., Larson, D. \& Butzer. R. (2002). Determinants of agricultural growth in Indonesia, the Philippines and Thailand. World Bank Policy Research Working Paper 2803. Retrieved from: https://papers.ssrn.com/ sol3/papers.cfm?abstract_id $=636086$

Ndebbio, J.E.U. (2006). The structural economic dimensions of underdevelopment, associated vicissitudes and imperative: Agenda for positive change. $33^{\text {rd }}$ Inaugural Lecture of the University of Calabar, Nigeria: Saesprint Publishers.

Obasaju, B. O., Oloni, F. E., Obadiaru, E. D. \& Rotimi, M. E. (2014). Macroeconomic policies and agricultural development in developing countries: Lessons from emerging economies. International Business and Management, 8(2), 84-91. DOI: 10.3968/4796

Odior, E.S. (2014). The macroeconomic policy effect on Nigerian agricultural performance: One-step dynamic forecasting analysis. International Journal of Economics and Finance, 6(9), 190-198, doi:10.5539/ijef.v6n9p190

Ogbuagu, U.R. \& Udo, Elijah (2012). Financial sector development and industrial production in Nigeria (1970-2009): An ARDL cointegration approach. Journal of Applied Finance \& Banking, 2(4), 49-68.

Ogunleye, O., Ajibola, A., Enilolobo, O. \& Shogunle, O. (2018). Influence of road transport infrastructure on agricultural sector development in 
Nigeria. Logistics \& Sustainable Transport, 9(1), 39-50. Doi: 10.2478. Ojo, M.O. (1991). The effectiveness of agricultural policies on Nigeria's economic development. In J. Ndebbio \& A. Ekpo (Eds.), The Nigerian Economy at the Crossroads: Policies and their Effectiveness (pp. 33-59). Calabar, Nigeria: University of Calabar Press.

Oladipo, S.O. \& Ayegbusi, O. (2016). Dynamic interactions among road transport infrastructure development, agriculture growth and poverty level in Nigeria (1980-2012), In Attaining inclusive growth in Nigeria: prospects and challenges. Selected papers from the 2015 annual conference of the Nigerian Economic Society (NES).

Olakunle, O. T. (2013). Trends and limitations of some selected macroeconomic policies on the Nigerian agriculture. European Journal of Business Management, 5(32), 84-97.

Oyefusi, S. A. \& Udoh, E. (2004). Openness, trade liberalization and economic growth in developing countries. Nigerian Journal of Economics and Development Matter, 3, 25-43.

Pesaran, M. H., Shin, Y. \& Smith, R. J. (2001). Bound testing approaches to the analysis of level relationships. Journal of Applied Econometrics, 16, 289-326. https://doi.org/10.1002/jae.616

Pinstrup-Andersen \& Shimokawa (2006). Rural infrastructure and agricultural development. Paper presented at the Annual Bank Conference on Development Economics, Tokyo, Japan, May 29-30

Posu, S.M.A. (2006). Information and communication technologies in the Nigerian economy. International Conference on Human and Economic Resources, Izmir.

PowerGen Statistics (2015). http://www.powergen-statistics.com

Ricardo, D. (1817). On the principles of political economy and taxation. Available online at the Library of Economics and Liberty: http://www. econlib.org/library/Ricardo/ricP.html

Sanusi, S. L. (2012). Infrastructure, industrialisation and the Nigerian Economy. Paper Presented at the Second Public Lecture of Kresta Laurel Limited in Lagos.

Shuaib, I. M., Igbinosun, F.E. \& Ahmed, A.E. (2015). Impact of government agricultural expenditure on the growth of the Nigerian economy. Asian Journal of Agricultural Extension, Economics \& Sociology, 6(1), 23-33, DOI: 10.9734/AJAEES/2015/15369

Solow, R. M. (1956). A contribution to the theory of economic growth. Quarterly 
Journal of Economics, 70, 65-94. https://doi.org/10.2307/1884513

Swan, T. (1956). Economic growth and capital accumulation. Economic Record, 32(63), 334-361. https://doi.org/10.1111/j.1475-4932.1956. tb00434. $\mathrm{x}$

Ubi, P.S. Eke, F.A. \& Oduneka, A.E. (2011). The role of infrastructure in industrialisation in a developing economy: The case of electricity supply and education in Nigeria. In E. Udoh, U. R. Ogbuagu \& U. Essia (Eds.), Industrial Development: A Catalyst for Rapid Economic Growth. Essays in Honour of John Emmanuel Ndebbio (pp. 109-122). P.N. Davison Publications.

Udah, E.B. (2010). Industrial development, electricity crisis and economic performance in Nigeria. European Journal of Economics, Finance and Administrative Sciences, 18.

World Bank. (2017). World Development Indicators. Retrieved from: https:// openknowledge.worldbank.org/handle/10986/21634 